\title{
INFLUENCE OF SOWING DATE ON YIELD AND ITS COMPONENTS FOR SOME TRITICUM DURUM CULTIVARS HAVING THERMAL RESPONSES IN MIDDLE EGYPT
}

\author{
EL-SAWI, S. A. AND A. T. H. MOUSTAFA \\ Wheat Research Dept., Field Crop Res. Inst., ARC, Giza, Egypt.
}

(Manuscript received 11 September 2014)

\begin{abstract}
The present investigation was carried out at Mallawy Agricultural Research Station, El-Minia Governorate, Egypt during the two successive seasons; 2010/ 2011 and 2011/2012. The objective of this investigation was to study the effect of sowing dates expressed in the accumulated temperature on yield and its components of three durum wheat genotypes (Triticum durum), i.e., Beni sweif- 1 , Beni sweif- 4 and Beni sweif- 5 in three sowing dates, namely; $21^{\text {st }}$ November, $10^{\text {th }}$ December and $30^{\text {th }}$ December during the two winter growing seasons. The studied characteristics included plant height, and number of spikes $/ \mathrm{m}^{2}$, number of kernels/spike, 1000-kernel weight, grain yield, straw yield and grain filling period. The results showed that all the sowing dates and cultivars reached to maturity at 140.2 days after sowing (DAS) $\left(1652.2^{\circ} \mathrm{C}\right.$ days) in season 1 and at 152.4 DAS $\left(2016.4^{\circ} \mathrm{C}\right.$ days) in season 2 . Heading date and anthesis were significantly affected by cultivars and sowing dates in both growing seasons, also the interaction in the second season. Days to maturity were significantly affected by sowing dates in the two growing seasons and cultivars in the first season. Plant height was significantly affected by cultivars and sowing dates in both growing seasons; also significant interaction was observed between cultivars and sowing dates in the second season only. Number of spikes $/ \mathrm{m}^{2}$ was significantly affected by sowing dates in both growing seasons; also cultivars in the second season on spike/ $\mathrm{m}^{2}$. Number of kernels/spike and thousand kernel weight were significantly affected by cultivars, sowing dates and the interaction between cultivars and sowing dates in the second season only. Grain yield/plot was significantly affected by sowing dates in both growing seasons and cultivars in the second season. Straw yield was significantly affected by sowing dates in both growing seasons because the sowing dates (thermal time) was the main limiting factor to straw and grain yield in two growing seasons 2010/2011 and 2011/2012. Grain filling period was significantly affected by sowing date in both growing seasons and the interaction cultivar $\times$ sowing date was significant in the second season. The current study showed that the first sowing date was the optimum date for Beni sweif-1 in both growing seasons. These results are discussed in relation to future improvement of yield in respect to the variation of meteorological data in winter season with a spot light on thermal time.
\end{abstract}

Key words: Sowing date, Thermal time, Cultivars, Triticum durum, phenology. 


\section{INTRODUCTION}

In Egypt, the response of both grain and straw yields to different sowing dates have greatly varied according to different environmental conditions (for temperature and light) and cultivars of cereal crops, specially durum wheat. In the Mediterraneantype environment of Western Australia, a study was conducted to identify the changes and to examine whether further yield improvement is possible from the same trends Siddique et. al. (1989) suggested that increase in grain yield (in recent CIMMYT durum wheat cultivars released after 1975) was mainly due to increased biomass with little change in harvest index.David et. al. (2012) reported that in the near future (2020-2049) a small to nill increase in heat stress may occur. In the far future (2070-2099), the frequency of heat stress during grain filling increase significantly. Adaptation through earlier sowing dates proves to be the least efficient. Use of earlier heading cultivars is somewhat efficient, and should be sufficient for the near future. Tolerance to heat stress appears to be the most promising adaptation strategy. Too early sowing of durum produces weak plants with poor root system. In addition, during too early sowing the temperature is above the optimum, which leads to irregular germination caused by frequent death of embryos and decomposition of endosperm due to bacteria or fungi and late sowing reduced 100 grain weight (Mazalrek and Kns 1991). Grain yield was increased by early planting. A significant advantage of date 2 planting was recorded at Kemptville (Lat. $45^{\circ} 00^{\prime}$ ) in Canada. Kernel weight and test weight were reduced by late planting dates. Cultivars effects on grain yields were frequently significant, but were less on winter wheat survival (Andrews et. al. 1992).Gardener et. al. (1993) reported that in southern USA spring type wheat cultivars are adapted to wider range of planting dates than winter type and recommended early planting of winter type wheat cultivars because of their vernalizatin requirement. Wheat late planting resulted in significant reduction in grain yield even though more spikes per square meter were produced. However, reduced yield due to a decrease in kernel weight and kernel number per spike, but the magnitude of yield loss was reduced by using an early-maturing cultivar (Shah et al., 1994). In another study. Hameed et. al. (2003) concluded that days to emergence, tillers $/ \mathrm{m}^{2}$, days to heading and plant height were significantly affected by different planting dates, seed rates and $\mathrm{N}$ levels. Tammam and Tawfelis, (2004) reported that early sowing date produced the highest number of spikes $/ \mathrm{m}^{2}$, number of kernels/spike, heaviest kernel weight, highest biological and grain yields which were significant in the recommended compared to the late dates planting. The analysis of variance showed highly differences among cultivars for all studied characters. The 
interaction between sowing date and cultivars had significant effect on all studied characters. Abdel-Nour and Hayam (2011) reported that all studied characters (days to heading and maturity, plant height, number of spikes $/ \mathrm{m}^{2}$, number of kernels/spike, kernel weight, biological and grain yield) were significantly higher in the recommended compared to the late dates of planting. The analysis of variance showed highly significant differences among cultivars for all studied characters and also the interaction. Tawfelis et al, (2011) reported that the combined analysis of variance showed highly significant differences among planting dates and genotypes for all studied traits, i.e., days to maturity, plant height, peduncle length, flag leaf area and straw yield. Meanwhile, genotypes $x$ environments interaction mean squares were highly significant for all studied characters except for peduncle length. The aim of this study is to determine the effect of sowing dates; the accumulated temperature or thermal time on the yield of durum wheat cultivars and its components.

\section{MATERIALS AND METHODS}

Two field experiments were conducted in the two successive seasons 2010/2011 and 2011/2012 at Mallawy Agric. Res. Sta., ARC, to study the effect of three sowing dates (accumulated temperature) on yield and yield components of three durum wheat (Triticum, turgidum var, durum) namely, Beni Sweif-1(heat tolerance), Beni Sweif-4 (heat sensitive) and Beni Sweif-5(moderately susceptible shown in Table(1). The studied treatments were: three sowing dates i.e. 21th of November (recommended date), 10th December (mediocrity date) and 30th December (late date).

Table 1. Name, origin and pedigree of three durum wheat cultivars.

\begin{tabular}{|c|c|c|c|}
\hline NO. & Parents & Pedigree & Year of release \\
\hline 1 & \multirow{2}{*}{ Beni sweif-1 } & Jo "S"/AA "S" // FG "S". & 1987 \\
\hline 2 & Beni sweif-4 & $\begin{array}{r}\text { AUSL/5/CAND01/4/BY*2TACE//II27655/3/TME//ZBW/*2. } \\
\text { ICD88-1120-ABL-0TR-1BR-0TR-6AP-0AP-0SD }\end{array}$ & 2007 \\
\hline 3 & Beni sweif-5 & Dipperz / Bushen & 2007 \\
\hline
\end{tabular}

A split-plot design in randomized complete blocks arrangement was used with three replications. Sowing dates were represented in the main-plots, while the three durum wheat cultivars were randomly distributed in the sub plots. Each plot consisted of 6 rows, $4 \mathrm{~m}$ long and $20 \mathrm{~cm}$ apart, plot size was $4.80 \mathrm{~m}^{2}$. 


\section{Studied characters:}

Days to $50 \%$ emergence, days to $50 \%$ anthesis, days to $50 \%$ maturity, grain filling period (days), Plant height ( $\mathrm{cm})$, Number of spikes $/ \mathrm{m}^{2}$, Number of kernels/spike and 1000-kernels weight $(\mathrm{g})$, straw yield ( $\mathrm{kg} / \mathrm{plot})$ and grain yield $(\mathrm{kg} / \mathrm{plot})$ were recorded. Moreover, grain filling period (days) was calculated as the difference between days to anthesis and to maturity. Four rows $\left(3.2 \mathrm{~m}^{2}\right)$ were kept for grain yield determination; the relation of 10 plant characteristics to yield of grain also was computed. The normal cultural practices of growing durum wheat in the region were followed. Degree-days for time to emergence, days to heading stage, days to anthesis and days to maturity were calculated by summing daily degree-days ( $T n)$, where daily degree-days were computed as: $\mathrm{Tn}=[(\mathrm{T} \cdot \mathrm{max}+\mathrm{T} \cdot \mathrm{min}) / 2]-\mathrm{Tb}$. Where T.max and T.min are the maximum and minimum daily air temperature, respectively and $\mathrm{Tb}$ is the base temperature $5^{\circ} \mathrm{C}$ bellow which no development occurs ( Przuij and Mladenove 1999). The data in these experiments were analyzed by ANOVA procedure using Michigan State University Package (MSTATC ver. 2). Replication was considered random, but sewing dates and durum wheat cultivars were fixed. Least significant difference (LSD) was used for treatment mean separations (Steel and Torrie, 1980).

\section{RESULTS AND DISCUSSION}

\section{1- Phenology}

Seasonal conditions temperature for November - May growing season (Tables 2 and 3) show the mean of temperatures for some characters, and its overall season.

Full details of phenological development for each cultivar as emergence, double ridge, heading, terminal spikelet, anthesis and physiological maturity are reported by Siddique et. al. (1989), Karimi and Siddique (1991) and Moustafa and El-Sawi (2014). Generally emergency, double ridge, heading, terminal spikelet and physiological maturity were significantly affected by thermal time.

The cultivars emerged together at 6.3 DAS $\left(70.8^{\circ} \mathrm{C}\right.$ days), reached heading stage at 82.2 DAS $\left(806.3^{\circ} \mathrm{C}\right.$ days), anthesis stage at 88.4 DAS $\left(880.1^{\circ} \mathrm{C}\right.$ days), and maturity at 140.2 DAS (1652.2 ${ }^{\circ} \mathrm{C}$ days) on average at the first season. The cultivars fell into two maturity groups similar to those described by thermal time in season 1 and season 2. Third sowing date of Beni Sweif- 1 cultivars resulted in heading stage at about 76.7 DAS (754.4 $\mathrm{C}$ days) season 1 and the maturity stage was attained at 128.7 DAS (1593.8 ${ }^{\circ} \mathrm{C}$ days) at the same season and produced the lowest biological yield $(5.733) \mathrm{kg} / \mathrm{plot}$. Also, the first sowing of Beni Sweif-1 cultivar resulted in heading 
stage at about 85.0 DAS ( $841.0^{\circ} \mathrm{C}$ days) in season 1 and the maturity stage at 148 DAS $\left(1691.0^{\circ} \mathrm{C}\right.$ days) and gave a biological yield of (10.867) kg/plot.

Across the two seasons, the cultivars emerged together at $8.2 \mathrm{DAS}\left(75.7^{\circ} \mathrm{C}\right.$ days), reached heading stage at 90.7 DAS $\left(865.9^{\circ} \mathrm{C}\right.$ days), anthesis stage at 98.4 DAS $\left(970.60^{\circ} \mathrm{C}\right.$ days) and maturity stage at 152.4 DAS (2016.4 ${ }^{\circ} \mathrm{C}$ days).

Third sowing date of Beni Sweif-4 cultivar reached heading stage at 89.3 DAS $\left(899.40^{\circ} \mathrm{C}\right.$ days $)$ in season 2 and maturity stage at 150.3 DAS $\left(2255.6^{\circ} \mathrm{C}\right.$ days $)$ and recorded the lowest biological yield in the second season (5.000) kg/plot) (Table4). However, first sowing date of Beni sweif-1 cultivar reached heading stage at 89.7 DAS (829.9 $\mathrm{C}$ days) in season 2 and maturity stage at 161.0 DAS $\left(1971.7^{\circ} \mathrm{C}\right.$ days) and gave the highest biological yield $(8.600 \mathrm{Kg} / \mathrm{plot})$.

\section{2- Plant height}

Beni sweif-1 was the shortest cultivar for plant height in the three planting dates, while the cultivar Beni sweif-4 was the tallest in the first and second sowing dates. Moreover, cultivar Beni sweif-1 had the shortest plant in the third sowing date (Table 4).

The mean of plant height across all cultivars in season 1 was $104.9 \mathrm{~cm}$, while it was $99.7 \mathrm{~cm}$ in season2. It is clear that across the two growing seasons late planting dates caused a reduction in plant height in the second and third planting dates. This could be explained as long plant duration gave a maximum vegetative growth when planting was carried out early. These results are in harmony with those obtained by Hameed et. al. (2003), Tawfelies et. al. (2011) and Abdel-Nour and Hayam (2011) and Moustafa and El-Sawi (2014).

The effects of cultivars and sowing dates on plant height were significant in both growing seasons and the interaction in second season was also significant due to the thermal time (Table 4). Similar results were also reported by Hameed et. al. (2003), Abdel-Nour and Hayam (2011) and Moustafa and El-Sawi (2014).

\section{3-Heading}

Results in Table (2) show that durum cultivars were significantly different in their heading date in both growing seasons. Beni sweif-1 was the latest cultivar in heading at first season and Beni sweif- 4 at second season, whereas Beni sweif- 5 was the earliest cultivar in heading at first season and Beni sweif-1 at second season. The obtained results were in agreement with those of El-Sawi (1996), Tammam and Tawfelis (2004), Abdel-Nour and Hayam (2011), David et. al. (2012), Zunfu et. al. (2013) and Moustafa and El-Sawi (2014).

The results in Table (2) showed that, sowing date had significant effect on 50\% heading stage in the two seasons. Third sowing was the earliest in heading, i.e. at 
76.3 days, 88.4 days compared with first and second sowing in both sowing seasons respectively.

Similar results were reported by Hameed et. al. (2004), Tammam and Tawfelis (2004), Abdel-Nour and Hayam (2011), David et. al. (2012), Zunfu et. al. (2013) and Moustafa and El-Sawi (2014).

The interaction between cultivars and sowing dates significantly influenced the heading date in second season only where cultivars of Beni sweif-4 or Beni sweif-5 sown at the third date were the earliest due to the thermal time. Similar results were reported by Tammam and Tawfelis (2004), Abdel-Nour and Hayam (2011) and Moustafa and El-Sawi (2014).

\section{4-Anthesis}

The results in Table (2) show that, wheat cultivars differed significantly in their anthesis in both of growing seasons, Beni sweif-4 was the latest cultivar in anthesis compared with the other two cultivars. On the other hand, Beni-Sweif5 was the earliest cultivar in anthesis at first season; however, Beni sweif-1 was the earliest cultivar in anthesis at the second season. The results indicated significant differences between cultivars and sowing dates in this trait for both seasons, but their interaction significantly affected this trait only in the second season due to the thermal time. These results were also in accordance with those of Siddique et. al. (1989), David et. al. (2012), Zunfu et. al. (2013) and Moustafa and El-Sawi (2014).

Mean of days to anthesis for third sowing date showed earliest anthesis date of 83.4 days at first season and 93.4 days for the second season compared with the first and second sowing dates in both seasons. Mean first sowing date showed latest in anthesis 102.3 days in the second growing season. This may be due to the higher temperatures at the third sowing date than those of other sowing dates at the time of anthesis

\section{5-Maturity}

Data of Table (2) show that Beni sweif-5 was the earliest cultivar in maturity date than Beni sweif-1 and Beni sweif-4 whereas significant differences were detected between cultivars in the first season only.

The results reported by Shah, et. al. (1994) El-Sawi (1996), Hameed et. al. (2004), Abdel-Nour and Hayam (2011)), Tawfelis et. al. (2011), Zunfu et. al. (2013) and Moustafa and El-Sawi (2014) showed that cultivars affected heading and maturity dates of wheat.

The results in Table (2) show that sowing date significantly affected maturity date in the two growing seasons. Mean first sowing time showed the latest in maturity; 146.8 days in first season and 161.7 days in second season. Mean third 
sowing time was the earliest in maturity date; 127.4 days at first season and 149.4 days at second season compared with the other studied sowing times. The conclusion is that developmental characters, i.e., heading, anthesis and maturity dates were delayed 3-22 days in the second season because of the thermal time response. The interaction cultivar $x$ sowing date on maturity was not significant in both growing seasons. Such results were in agreement with those of Hameed (2003) and AbdelNour and Hayam (2011). Also the results obtained by Shah et. al. (1994), Hameed et al.(2003), Abdel-Nour and Hayam (2011), Tawfelis et. al. (2011), David et. al. (2012), Zunfu et. al. (2013) and Moustafa and El-Sawi (2014), who showed that maturity date was affected by sowing date.

\section{6- Number of spikes $\mathbf{~ m}^{-2}$}

Data of Table (4) show that the results in the first season, revealed that number of spikes $\mathrm{m}-2$ was significantly increased in the optimum sowing date (1670.1 $\circ \mathrm{C}$ days) as compared with late sowing (1562.6 ${ }^{\circ} \mathrm{C}$ days) with an average of 483 , 459 and 389 in the first, second and third sowing date, respectively while in the second season, it was 491, 452 and 421 in the first, second and third sowing date, respectively. This could be due to that the climatologically conditions prevailing accumulated temperature during the recommended sowing date favored to the production of fertile tillers. These results are in general agreement with those reported by Shah et al.(1994), Tammam and Tawfelis (2004), Abdel-Nour and Hayam (2011), Tawfelis et. al. (2011) and Moustafa and El-Sawi (2014). The durum wheat cultivar Beni Sweif-1 produced higher number of spikes $m-2$ than Beni Sweif- 4 and Beni Sweif- 5 in the first season. While Beni Sweif-5 produced higher number of spikes $/ \mathrm{m}^{2}$ in the second season. It could be concluded that marked genetically differences existed among the 3 evaluated cultivars. Those results coincide with those obtained by Shah et. al. (1994), Tammam and Tawfelis (2004), Abdel-Nour and Hayam (2011) and Moustafa and El-Sawi (2014). The analysis for spikes $\mathrm{m}-2$ showed that sowing date in both growing season, cultivars in the second season and the interaction cultivars $\times$ sowing dates in the first season was significant (Table 4).

\section{7- Number of kernels / spike}

Results in Table (4) indicates that cultivars, sowing dates and the interaction between them significantly affected number of kernels / spike in the second season only.

The normal sowing date (recommended) produced higher number of kernels/spike compared with late sowing in the second season. The average number of kernels/spike for durum wheat genotypes varied from 65 to 71 in the first season and from 55 to 57 in the second season (Table 4). The behavior of these cultivars 
could be attributed to the different genetic backgrounds of the studied genotypes. These findings are in agreement with those reported by Siddique et. al. (1989), Shah et al.(1994), Tammam and Tawfelis, (2004), Abdel-Nour and Hayam (2011) and Moustafa and El-Sawi (2014).

\section{8- Kernel weight}

Results in Table (4) shows that plots sown at optimum date (21st November) produced heavier kernel than those at late sowing (30th December). Thousand kernels weights were decreased proportionally as the planting was delayed. Meanwhile, at the optimum planting, the plants had suitable and longer thermal time (accumulated temperature) for vegetative growth, which resulted in the active photosynthesis and maximum translocation of the assimilates to the kernel and thus had heavier kernels. Mazalrek and Kns (1991), Andrews et. al. (1992), Shah et al. (1994), Tammam and Tawfelis (2004), Hameed et. al. (2004) and Abdel-Nour and Hayam (2011) reported that early sowing gave maximum grain weight and grain yield compared with late one.

Meanwhile, Beni sweif-4 and Beni-Sweif-5 had the heaviest 1000 kernel weight in the first and in the second season respectively. It could be concluded that the three tested cultivars showed no stability in this character which behaved differently from one season to the other (Table 4). The differences in 1000 kernel weight among wheat cultivars were reported by Andrews et. al. (1992), Shah et. al. (1994), Tammam and Tawfelis (2004), Hameed et. al. (2003), Abdel-Nour and Hayam (2011).

The analysis for 1000 kernel weight showed that cultivars, sowing dates and the interaction between them significantly affected this trait in the second season only (Table 4).

\section{9- Straw yield/plot}

The results in Table (4) showed that the optimum planting date induced an increase in straw yield in both seasons, similar to its effect on grain yield. These results are confirmed by Siddique et. al. (1989), Tammam and Tawfelis (2004), AbdelNour and Hayam (2011) and Tawfelis et. al. (2011) who concluded that sowing at optimum time gave the highest straw yield.

The three studied cultivars had marked differences in their straw yield, in both seasons (Table 4). Beni Sweif-1 cultivar produced the highest straw yield in both seasons. These results showed that the studied cultivars differed in their yield potentiality. The differences in straw yield among wheat cultivars were reported by many investigators (Siddique et. al. 1989, Tammam and Tawfelis 2004, Abdel-Nour 
and Hayam 2011 and Tawfelis et. al. 2011). The results in Table (4) showed that sowing date significantly affected straw yield in both growing seasons.

\section{0- Grain yield/plot (kg)}

Results in Table (3) showed that planting date treatments affected grain yield/plot $(\mathrm{kg})$ in both seasons, where mean of the first sowing date $\left(1670.1^{\circ} \mathrm{C}\right.$ days) accumulated temperature in season 1 at maturity , and (1987.1 ${ }^{\circ} \mathrm{C}$ (days)) accumulated temperature in season 2 at maturity gave highly significant grain yield (Table 3). Although the mean of late sowing date $1562.6{ }^{\circ} \mathrm{C}$ days accumulated temperature in season 1 at maturity, $2237.1{ }^{\circ} \mathrm{C}$ days accumulated temperature in season 2 at maturity gave lower grain yield (Table 3 ). The mean yield reduction due to the late sowing ranged from 1.203 in season 1 to $0.931 \mathrm{~kg} /$ plot in season 2 (Table4).

Delaying the sowing date decreased grain yield due to the decrease in kernel weight, kernel number/spike and spikes $/ \mathrm{m}^{2}$. Furthermore, analysis of data revealed that sowing at optimum time favored the maximum partitioning of photosynthesis when compared to the late sowing and gave maximum grain yield (Table 4). Also, there was a sufficient time available for plant growth and development at early sowing. Similar results have also been reported by Andrews et al.(1992), Gardener et al.(1993), Shah et al.(1994), Hameed et. al. (2004), Tammam and Tawfelis (2004), and Abdel-Nour, and Hayam (2011). The evaluated durum cultivars differed in grain yield $\mathrm{kg} / \mathrm{plot}$ in the two growing seasons (Table4). The average grain yield showed that the cultivar Beni Sweif-5 gave the highest yield in the first season while, the cultivar Beni Sweif-1 gave the highest yield in the second season.

The results indicate differences among cultivars in their productivity under different sowing dates as confirmed by many investigations (Andrews et. al. 1992, Gardener et al.1993, Shah et. al. 1994, Hameed et. al. 2004, Tammam and Tawfelis 2004, and Abdel-Nour and Hayam 2011).

The analysis of variance for grain yield in $\mathrm{kg} / \mathrm{plot}$ (Table 4) showed that sowing date had a significant effect in both growing seasons and cultivars in the second season $(P \leq 0.05)$ on grain yield.

These results led to a conclusion that the highest grain yield of durum wheat cultivar Beni Sweif-1 was obtained from the earliest sowing date for both growing seasons (Table 4). This result aims to identify these changes and examine thermal time, further yield and yield components improvements.

\section{1- Grain filling period (days)}

The results in Table (4) showed that, sowing dates significantly affected grain filling period in both growing seasons. It could be noticed that the grain filling period 
which was 55.8 and 59.3 days in season 1 and 2 resulted from the first sowing date, hence such sowing date elongated grain filling period by $0.4,11.8$ days in season one and 12.4, 3.3 days in season two compared with second and third sowing date respectively. It could be concluded that, first sowing date combined with an elongation in grain filling period produced higher biological yield in seasons 1 and 2 . Similar results were obtained by David et. al. (2012) and Zunfu et. al. (2013) who showed that grain filling period was affected by sowing date and thermal time.

The results in Table (4) showed also that interaction between cultivars and sowing dates significantly affected grain filling period in the second season only.

Beni sweif-1 cultivar had grain filling period of 56.7 and 61.3 days (Table 2) was the longest in grain filling period compared with Beni sweif-4 and Beni sweif-5.

It could be concluded that Beni sweif-1 combined longer grain filling period was superior in biological yield compared with the other two studied cultivars in season 1and 2.

The results obtained by Siddique et al.(1989), David et. al. (2012) and Zunfu et. al. (2013) showed that grain filling period was affected by cultivars. 
Table 2. Days to $50 \%$ emergency, heading, anthesis and maturity for the cultivars and sowing dates.

\begin{tabular}{|c|c|c|c|c|c|c|c|c|c|c|c|c|c|c|c|c|c|}
\hline & \multirow[b]{2}{*}{ cultivars } & \multicolumn{4}{|c|}{ Days to emergence } & \multicolumn{4}{|c|}{ Days to heading stage } & \multicolumn{4}{|c|}{ Days to anthesis } & \multicolumn{4}{|c|}{ Days to maturity } \\
\hline & & First & Secon & Third & mean & First & Secon & Third & mean & First & Secon & Third & Mean & First & Second & Third & mean \\
\hline \multirow{4}{*}{ 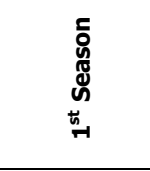 } & Beni sweif-1 & 6.3 & 7.3 & 7.7 & 7.1 & 85.0 & 88.7 & 76.7 & 83.4 & 91.3 & 91.3 & 84.3 & 89.0 & 148.0 & 147.0 & 128.7 & 141.2 \\
\hline & Beni sweif-4 & 4.3 & 7.3 & 6.7 & 6.1 & 84.7 & 87.0 & 78.0 & 83.2 & 92.3 & 91.7 & 84.0 & 89.3 & 148.0 & 147.0 & 127.7 & 140.9 \\
\hline & Beni sweif-5 & 5.3 & 5.7 & 6.0 & 5.7 & 80.0 & 85.7 & 74.3 & 80.0 & 89.3 & 89.7 & 82.0 & 87.0 & 144.3 & 145.0 & 126.0 & 138.4 \\
\hline & Mean & 5.3 & 6.8 & 6.8 & 6.3 & 83.2 & 87.1 & 76.3 & 82.2 & 91.0 & 90.9 & 83.4 & 88.4 & 146.8 & 146.3 & 127.4 & 140.2 \\
\hline \multirow{3}{*}{ LSD at $5 \%$} & A & \multicolumn{4}{|c|}{$0.51 *$} & \multicolumn{4}{|c|}{$2.24 *$} & \multicolumn{4}{|c|}{$1.48^{*}$} & \multicolumn{4}{|c|}{$0.86 *$} \\
\hline & B & \multicolumn{4}{|c|}{$0.50 *$} & \multicolumn{4}{|c|}{$2.09 *$} & \multicolumn{4}{|c|}{$0.97 *$} & \multicolumn{4}{|c|}{$1.98^{*}$} \\
\hline & $A \times B$ & \multicolumn{4}{|c|}{--} & \multicolumn{4}{|c|}{--} & \multicolumn{4}{|c|}{--} & \multicolumn{4}{|c|}{--} \\
\hline \multirow{4}{*}{ 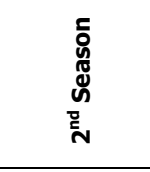 } & Beni sweif-1 & 6.3 & 8.0 & 10.0 & 8.1 & 89.7 & 89.3 & 86.7 & 88.6 & 99.7 & 98.3 & 93.0 & 97.0 & 161.0 & 147.0 & 149.3 & 152.4 \\
\hline & Beni sweif-4 & 5.7 & 9.0 & 10.3 & 8.3 & 96.0 & 90.7 & 89.3 & 92.0 & 104.7 & 99.3 & 93.7 & 99.2 & 162.7 & 145.3 & 150.3 & 152.8 \\
\hline & Beni sweif-5 & 5.7 & 9.3 & 9.0 & 8.0 & 94.3 & 91.0 & 89.3 & 91.6 & 102.7 & 100.3 & 93.7 & 98.9 & 161.3 & 146.3 & 148.7 & 152.1 \\
\hline & Mean & 5.9 & 8.8 & 9.8 & 8.2 & 93.3 & 90.3 & 88.4 & 90.7 & 102.3 & 99.3 & 93.4 & 98.4 & 161.7 & 146.2 & 149.4 & 152.4 \\
\hline \multirow{3}{*}{ LSD at $5 \%$} & A & \multicolumn{4}{|c|}{--} & \multicolumn{4}{|c|}{$1.26 *$} & \multicolumn{4}{|c|}{$1.10 *$} & \multicolumn{4}{|c|}{--} \\
\hline & B & \multicolumn{4}{|c|}{$0.87 *$} & \multicolumn{4}{|c|}{$0.73 *$} & \multicolumn{4}{|c|}{$1.23 *$} & \multicolumn{4}{|c|}{$1.88^{*}$} \\
\hline & A $\times B$ & \multicolumn{4}{|c|}{-- } & \multicolumn{4}{|c|}{$1.27 *$} & \multicolumn{4}{|c|}{$2.13 *$} & & & & \\
\hline
\end{tabular}


Table 3. GDD (Growing Degree Days) for the emergence stage, heading, anthesis and maturity for cultivars and sowing dates.

\begin{tabular}{|c|c|c|c|c|c|c|c|c|c|c|c|c|c|}
\hline & \multirow[t]{2}{*}{ cultivars } & \multicolumn{4}{|c|}{ Days to emergence } & \multicolumn{4}{|c|}{ Days to heading stage } & & & & \\
\hline & & First & Second & Third & Mean & First & Second & Third & mean & & & & \\
\hline \multirow{4}{*}{ 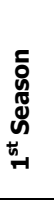 } & Beni sweif-1 & $90.3^{\circ} \mathrm{C}$ & $68.9^{\circ} \mathrm{C}$ & $75.8^{\circ} \mathrm{C}$ & $78.3^{\circ} \mathrm{C}$ & $841.0^{\circ} \mathrm{C}$ & $873.3^{\circ} \mathrm{C}$ & $754.4^{\circ} \mathrm{C}$ & $822.9^{\circ} \mathrm{C}$ & & & & \\
\hline & Beni sweif-4 & $64.4^{\circ} \mathrm{C}$ & $68.9^{\circ} \mathrm{C}$ & $69.1^{\circ} \mathrm{C}$ & $67.5^{\circ} \mathrm{C}$ & $841.0^{\circ} \mathrm{C}$ & $844.5^{\circ} \mathrm{C}$ & $765.8^{\circ} \mathrm{C}$ & $817.1^{\circ} \mathrm{C}$ & & & & \\
\hline & Beni sweif-5 & $77.5^{\circ} \mathrm{C}$ & $60.2^{\circ} \mathrm{C}$ & $62.1^{\circ} \mathrm{C}$ & $66.6^{\circ} \mathrm{C}$ & $785.3^{\circ} \mathrm{C}$ & $830.0^{\circ} \mathrm{C}$ & $721.6^{\circ} \mathrm{C}$ & $779.0^{\circ} \mathrm{C}$ & & & & \\
\hline & Mean & $77.4^{\circ} \mathrm{C}$ & $66.0^{\circ} \mathrm{C}$ & $69.0^{\circ} \mathrm{C}$ & $70.8^{\circ} \mathrm{C}$ & $822.4^{\circ} \mathrm{C}$ & $849.3^{\circ} \mathrm{C}$ & $747.3^{\circ} \mathrm{C}$ & $806.3^{\circ} \mathrm{C}$ & & & & \\
\hline \multirow{6}{*}{ 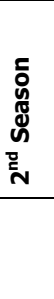 } & Beni sweif-1 & $64.5^{\circ} \mathrm{C}$ & $73.9^{\circ} \mathrm{C}$ & $84.6^{\circ} \mathrm{C}$ & $74.3^{\circ} \mathrm{C}$ & $829.9^{\circ} \mathrm{C}$ & $823.2^{\circ} \mathrm{C}$ & $871.9^{\circ} \mathrm{C}$ & $841.7^{\circ} \mathrm{C}$ & & & & \\
\hline & Beni sweif-4 & $64.5^{\circ} \mathrm{C}$ & $84.0^{\circ} \mathrm{C}$ & $84.6^{\circ} \mathrm{C}$ & $77.7^{\circ} \mathrm{C}$ & $899.1^{\circ} \mathrm{C}$ & $851.4^{\circ} \mathrm{C}$ & $899.4^{\circ} \mathrm{C}$ & $883.3^{\circ} \mathrm{C}$ & & & & \\
\hline & Beni sweif-5 & $64.5^{\circ} \mathrm{C}$ & $84.0^{\circ} \mathrm{C}$ & $76.4^{\circ} \mathrm{C}$ & $75.0^{\circ} \mathrm{C}$ & $867.5^{\circ} \mathrm{C}$ & $851.4^{\circ} \mathrm{C}$ & $899.4^{\circ} \mathrm{C}$ & $872.8^{\circ} \mathrm{C}$ & & & & \\
\hline & Mean & $64.5^{\circ} \mathrm{C}$ & $80.6^{\circ} \mathrm{C}$ & $81.9^{\circ} \mathrm{C}$ & $75.7^{\circ} \mathrm{C}$ & $865.5^{\circ} \mathrm{C}$ & $842.0^{\circ} \mathrm{C}$ & $890.2^{\circ} \mathrm{C}$ & $865.9^{\circ} \mathrm{C}$ & & & & \\
\hline & cultivars & \multicolumn{4}{|c|}{ Days to anthesis } & \multicolumn{4}{|c|}{ Days to maturity } & \multicolumn{4}{|c|}{ Days for grain filling period } \\
\hline & & First & Second & Third & mean & First & Second & Third & mean & First & Second & Third & mean \\
\hline \multirow{4}{*}{ 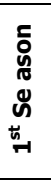 } & Beni sweif-1 & $908.1^{\circ} \mathrm{C}$ & $894.3^{\circ} \mathrm{C}$ & $850.7^{\circ} \mathrm{C}$ & $884.4^{\circ} \mathrm{C}$ & $1691.0^{\circ} \mathrm{C}$ & $1741.1^{\circ} \mathrm{C}$ & $1593.8^{\circ} \mathrm{C}$ & $1675.3^{\circ} \mathrm{C}$ & $788.0^{\circ} \mathrm{C}$ & $846.8^{\circ} \mathrm{C}$ & $743.1^{\circ} \mathrm{C}$ & $790.9^{\circ} \mathrm{C}$ \\
\hline & Beni sweif-4 & $918.8^{\circ} \mathrm{C}$ & $901.1^{\circ} \mathrm{C}$ & $850.7^{\circ} \mathrm{C}$ & $890.2^{\circ} \mathrm{C}$ & $1691.0^{\circ} \mathrm{C}$ & $1741.1^{\circ} \mathrm{C}$ & $1573.5^{\circ} \mathrm{C}$ & $1668.5^{\circ} \mathrm{C}$ & $772.2^{\circ} \mathrm{C}$ & $840.0^{\circ} \mathrm{C}$ & $722.8^{\circ} \mathrm{C}$ & $778.3^{\circ} \mathrm{C}$ \\
\hline & Beni sweif-5 & $889.9^{\circ} \mathrm{C}$ & $884.6^{\circ} \mathrm{C}$ & $822.8^{\circ} \mathrm{C}$ & $865.8^{\circ} \mathrm{C}$ & $1628.2^{\circ} \mathrm{C}$ & $1689.9^{\circ} \mathrm{C}$ & $1520.5^{\circ} \mathrm{C}$ & $1612.9^{\circ} \mathrm{C}$ & $738.3^{\circ} \mathrm{C}$ & $805.3^{\circ} \mathrm{C}$ & $867.1^{\circ} \mathrm{C}$ & $747.1^{\circ} \mathrm{C}$ \\
\hline & Mean & $905.6^{\circ} \mathrm{C}$ & $893.3^{\circ} \mathrm{C}$ & $841.4^{\circ} \mathrm{C}$ & $880.1^{\circ} \mathrm{C}$ & $1670.1^{\circ} \mathrm{C}$ & $1724.0^{\circ} \mathrm{C}$ & $1562.6^{\circ} \mathrm{C}$ & $1652.2^{\circ} \mathrm{C}$ & $764.5^{\circ} \mathrm{C}$ & $830.7^{\circ} \mathrm{C}$ & $721.2^{\circ} \mathrm{C}$ & $772.1^{\circ} \mathrm{C}$ \\
\hline \multirow{4}{*}{ 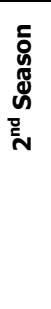 } & Beni sweif-1 & $943.5^{\circ} \mathrm{C}$ & $956.3^{\circ} \mathrm{C}$ & $963.9^{\circ} \mathrm{C}$ & $954.6^{\circ} \mathrm{C}$ & $1971.7^{\circ} \mathrm{C}$ & $1848.4^{\circ} \mathrm{C}$ & $2227.8^{\circ} \mathrm{C}$ & $2016.0^{\circ} \mathrm{C}$ & $1028.2^{\circ}$ & $892.1^{\circ} \mathrm{C}$ & $1263.9^{\circ} \mathrm{C}$ & $1061.4^{\circ} \mathrm{C}$ \\
\hline & Beni sweif-4 & $992.8^{\circ} \mathrm{C}$ & $966.4^{\circ} \mathrm{C}$ & $983.6^{\circ} \mathrm{C}$ & $980.9^{\circ} \mathrm{C}$ & $2018.0^{\circ} \mathrm{C}$ & $1802.1^{\circ} \mathrm{C}$ & $2255.6^{\circ} \mathrm{C}$ & $2025.2^{\circ} \mathrm{C}$ & $1025.2^{\circ}$ & $835.7^{\circ} \mathrm{C}$ & $1272.0^{\circ} \mathrm{C}$ & $1044.3^{\circ} \mathrm{C}$ \\
\hline & Beni sweif-5 & $969.0^{\circ} \mathrm{C}$ & $975.9^{\circ} \mathrm{C}$ & $983.6^{\circ} \mathrm{C}$ & $976.2^{\circ} \mathrm{C}$ & $1971.7^{\circ} \mathrm{C}$ & $1824.2^{\circ} \mathrm{C}$ & $2227.8^{\circ} \mathrm{C}$ & $2007.9^{\circ} \mathrm{C}$ & $1002.7^{\circ}$ & $848.3^{\circ} \mathrm{C}$ & $1244.2^{\circ} \mathrm{C}$ & $1031.7^{\circ} \mathrm{C}$ \\
\hline & Mean & $968.4^{\circ} \mathrm{C}$ & $966.2^{\circ} \mathrm{C}$ & $977.0^{\circ} \mathrm{C}$ & $970.6^{\circ} \mathrm{C}$ & $1987.1^{\circ} \mathrm{C}$ & $1824.9^{\circ} \mathrm{C}$ & $2237.1^{\circ} \mathrm{C}$ & $2016.4^{\circ} \mathrm{C}$ & $1018.7^{\circ}$ & $858.7^{\circ} \mathrm{C}$ & $1260.1^{\circ} \mathrm{C}$ & $1045.8^{\circ} \mathrm{C}$ \\
\hline
\end{tabular}


Table 4. Mean plant height, grain yield, straw yield, grain filling period and yield components of three durum wheat cultivars as affected by sowing dates.

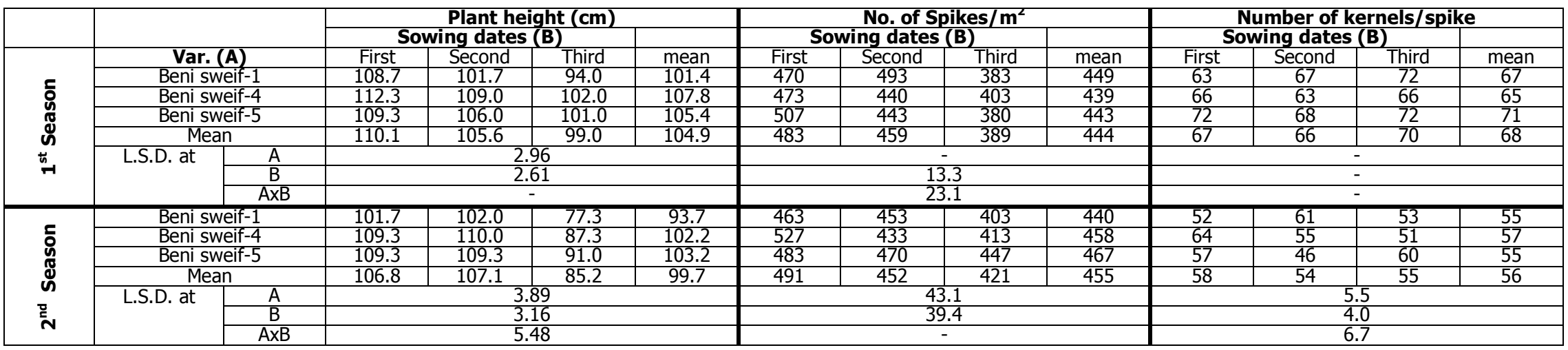

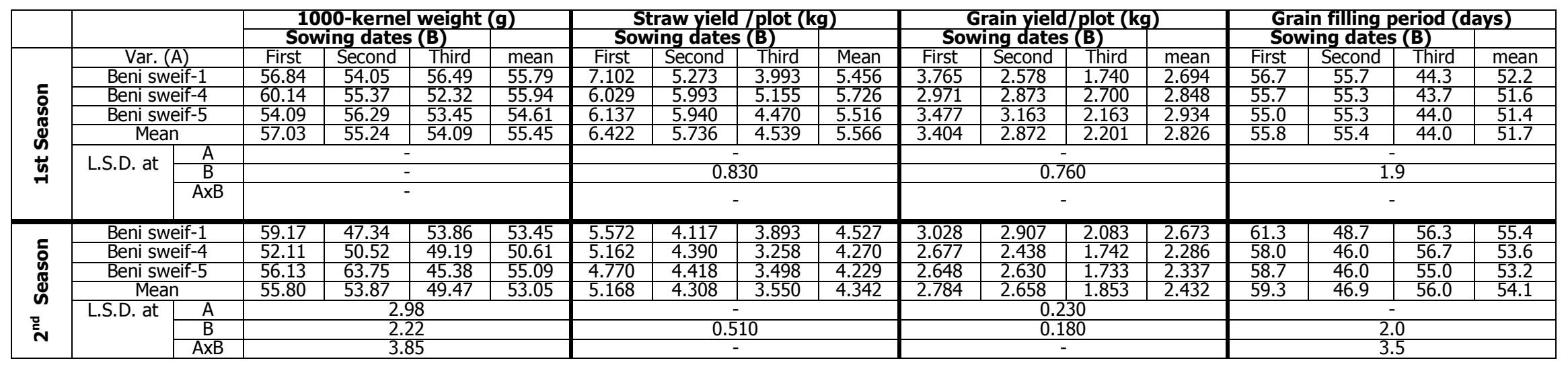




\section{REFERENCES}

1. Abdel Nour Nadya, A. R., and , Hayam, S. A. 2011. Influence of sowing date and nitrogen fertilization on yield and its components in some bread wheat genotypes. Egypt. J. Agric. Res., 89(4).

2. Andrews, C. J., Pomeroy, M. K.; Seaman, W. L., and Hoekstro, G. 1992. Planting dates and seeding rates for soft white winter wheat in eastern Ontario. Can. J. PI. Sci. 72: 391-402.

3. David, G., Xavier Le Bris, Matthieu B., Olivier D., Christian P. and Phlippe G. (012) Evaluating agronomic adaptation options to increasing heat stress under climate change during wheat grain filling in France. European Journal of Agronomy, 39:62-70.

4. Gardener, F.P.; Barnet, R. D.; Soffes, A. R., and Johnson, J. W. 1993. Reproductive development of eight wheat cultivars and a triticale as influenced by sowing date. Crop Sci. 33: 118-123.

5. Hameed, E.; Wajid, A. S.; Shad, A. A.; Jehan, B., and Tilah, M. 2003. Effect of different planting dates, seed rate and nitrogen levels on wheat. Asian J. PI. Sci., 2(6):467-474.

6. Karimi, M. M., and Siddique, K. H. M. 1991. Crop growth rates of old and modern wheat cultivars. Aust. J. Agric. Res., 42: 13-20.

7. El-Sawi, S. A. M. 1996. Evaluation of different wheat genotypes in relation to growth physiological characters and their contribution to grain yield. M. Sc. Thesis . Fac. Agric. Moshtohor, Zagazig Univ., Egypt.

8. Mazalrek, J., and Kns, J. 1991. Effect of nitrogen fertilizer application and sowing date rate on yield and quality of grain of spring wheat cultivars grown after different preceding crops. Bioletyn instytutn Hodowl: Aklimatyzeaji Roslin, 177: 123-136.

9. Moustafa,A.T. and El-Sawi, Sayed 2014. Influence of sowing date on development, harvest index and yield components for bread wheat cultivars having different thermal responses in middle Egypt. J.Agric.Sci. Mansoura Univ., 5(2):211-225.

10. Przuij, N., and Mladenove, N. 1999. Inheritance of grain filling duration in spring wheat. Plant breeding 118: 517-521.

11. Shah, S. A.; Harrison, D. J.; Boquet, P. D. Colyer, and Moore, S. H. 1994. Management effects on yield components of late planted wheat. Crop Sci. 34: 1298-1303. 
12. Siddique, K. H. M.; Belford, R. K.; Perry, M. W., and Tennant, D. 1989. Growth, development and light interception of old and modern wheat cultivars in a Mediterranean type environment. Aust. J. Agric. Res. 40: 473-487.

13. Steel, R.G.D., and J.H. Torrie 1980. Principles and procedures of statistics. A biometrical approach. 2.nd ed. Mc Graw-Hill Book Company, New York.

14. Tammam, A. M. and Tawfelis, M. B. 2004. Effect of sowing date and nitrogen fertilizer levels in relation to yield and yield components of durum wheat (Triticum turgidum var, durum) under upper Egypt environments. J. Agric. Sci. Mansoura Univ., 29(10): 5431-5442.

15. Tawfelis, M. B., Khieralla, K. A. A.; El Morshidy, M. A., and Feltaous, Y. M. 2011. Genetic diversity for heat tolerance in some bread wheat genotypes under Upper Egypt conditions. Egypt. J. Agric. Res., 89(4).

16. Zunfu Lv; Xiaojun liu; Weixing Cao, and Yan Zhu. 2013. Climate change impacts on regional winter wheat production in main wheat production regions of China. Agriculture and Forest Metreology 171-172:234-248. 


\title{
تأثير ميعاد الزراعة على المحصول ومكوناته فى بعض أصناف قمح الديورم واستجابتها للحرارة في مصر الوسطي
}

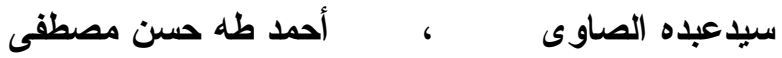 \\ قسم بحوث القمح - معهد بحوث الدحاصيل الحقلية - مركز البحوث الزراعية - الجيزة - مصر.
}

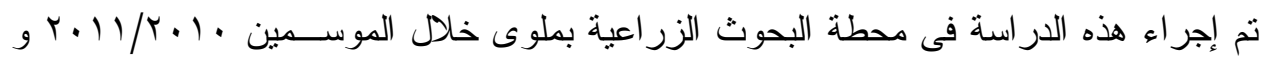

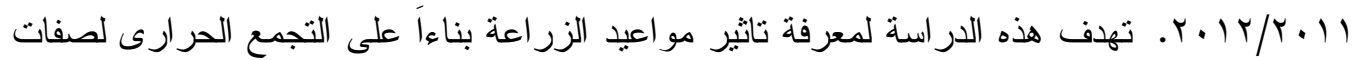

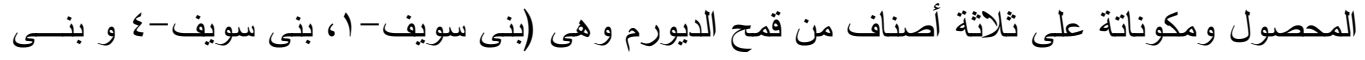

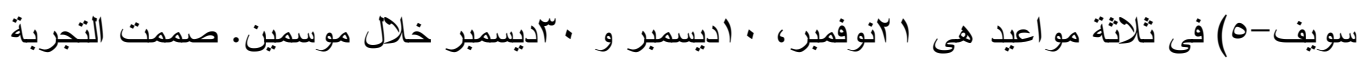

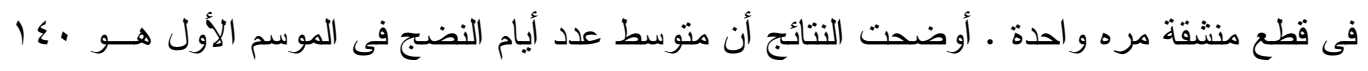

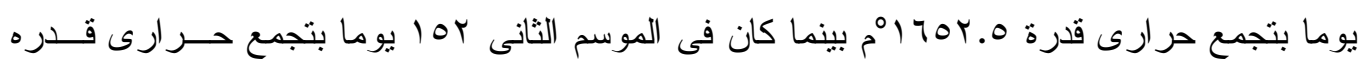

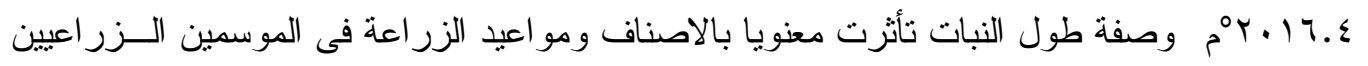

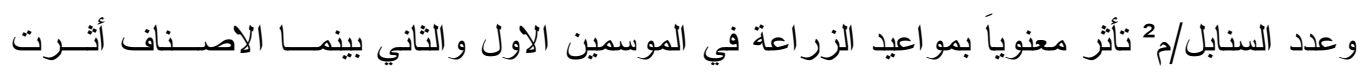

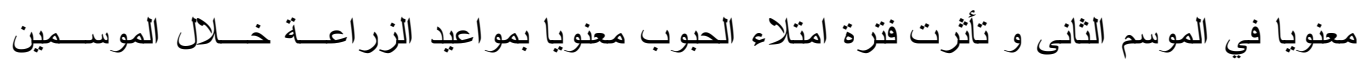

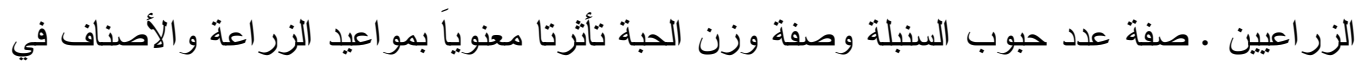

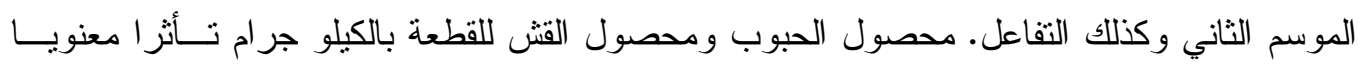
بمو اعيد الزر اعة فى الموسم الأول والثانى. بينما الاصناف أثزت معنويا في محصول الحبوب فقط في

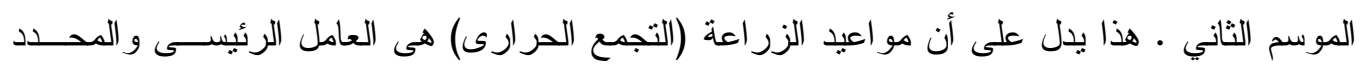

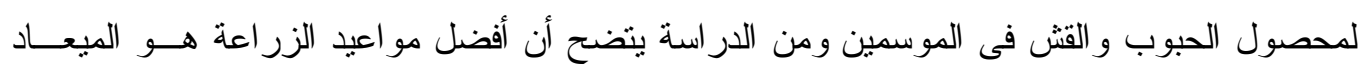
الأول و أفضل الأصناف محصو لَا هو الصنف بنى سويف-1 ولذلك يؤخذ فى اللإعنبار أن تحديد ميعاد الزر اعة المناسب يعتمد على الإحتياجات الحر ارية للصنف فى منطقة زر اعته. و الإختلاف فى نتــائج

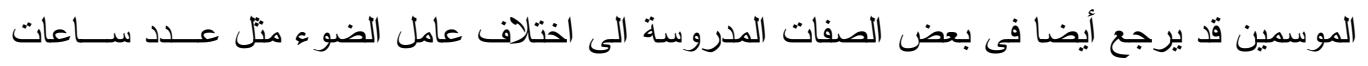
الإضاءة و شدة الإضاءه التى لم تؤخذ فى الإعتبار عند در اسة التجمع الحرارى. 